\title{
Methylated Xanthones from the Rootlets of Metaxya rostrata Display Cytotoxic Activity in Colorectal Cancer Cells
}

\author{
Eva Mittermair ${ }^{1,2, *}$, Hanspeter Kählig $^{3}$, Ammar Tahir $^{1}{ }^{\circledR}$, Stefanie Rindler ${ }^{1}$, Xenia Hudec ${ }^{2}$, \\ Hemma Schueffl $^{2}$, Petra Heffeter ${ }^{2}$, Brigitte Marian ${ }^{2}{ }^{-1}$ and Liselotte Krenn ${ }^{1}$ \\ 1 Department of Pharmacognosy, University of Vienna, Althanstraße 14, 1090 Vienna, Austria; \\ ammar.tahir@univie.ac.at (A.T.); stefanie.rindler@gmail.com (S.R.); liselotte.krenn@univie.ac.at (L.K.) \\ 2 Institute of Cancer Research, Department of Medicine I, and Comprehensive Cancer Center, Medical \\ University Vienna, Borschkegasse 8a, 1090 Vienna, Austria; xenia.hudec@meduniwien.ac.at (X.H.); \\ hemma.schueffl@meduniwien.ac.at (H.S.); petra.heffeter@meduniwien.ac.at (P.H.); \\ brigitte.marian@meduniwien.ac.at (B.M.) \\ 3 Department of Organic Chemistry, University of Vienna, Währingerstraße 38, 1090 Vienna, Austria; \\ hanspeter.kaehlig@univie.ac.at \\ * Correspondence: eva.mittermair@univie.ac.at
}

Academic Editor: Natalizia Miceli

Received: 15 September 2020; Accepted: 25 September 2020; Published: 28 September 2020

\begin{abstract}
AbstractThe tree fern Metaxya rostrata (Kunth) C. Presl is common in the rainforests of Central and South America, where suspensions of the dried rhizome are traditionally used to treat intestinal diseases. Two compounds from this plant, 2-deprenyl-rheediaxanthone $\mathrm{B}(\mathrm{XB})$ and 2-deprenyl-7-hydroxy-rheediaxanthone $\mathrm{B}(\mathrm{OH}-\mathrm{XB})$, have been shown to be biologically highly active against colorectal cancer (CRC) cells in previous studies. The current investigation resulted in the isolation of the previously undescribed methylated xanthones 2-deprenyl-6-O-methyl-7-hydroxyrheediaxanthone B, 2-deprenyl-5-O-methyl-7-methoxy-rheediaxanthone B, 2-deprenyl-5-O-methyl7-hydroxy-rheediaxanthone $B$ and 2-deprenyl-7-methoxy-rheediaxanthone $B$. All compounds were isolated by column chromatography, structures were elucidated by one- and two-dimensional NMR-experiments and the identities of the compounds were confirmed by LC-HRMS. In logarithmically growing SW480 CRC cell cultures, cytotoxicity by neutral red uptake and MTT assays as well as caspase activation was analyzed. Cellular targets were examined by Western blot, and topoisomerase I (topo I) inhibition potential was tested. Comparing the structure-activity relationship with $\mathrm{XB}$ and $\mathrm{OH}-\mathrm{XB}$, the monomethylated derivatives showed qualitatively similar effects/mechanisms to their nonmethylated analogues, while dimethylation almost abolished the activity. Inhibition of topo I was dependent on the presence of an unmethylated 7-OH group.
\end{abstract}

Keywords: Metaxya rostrata; metaxyaceae; 2-deprenyl-6-O-methyl-7-hydroxy-rheediaxanthone B; 2-deprenyl-5-O-methyl-7-methoxy-rheediaxanthone B; 2-deprenyl-5-O-methyl-7-hydroxy-rheediaxanthone B; 2-deprenyl-7-methoxy-rheediaxanthone B

\section{Introduction}

Metaxya rostrata (Kunth) C. Presl was first described in 1836, and is the only species of the genus Metaxya that has been investigated phytochemically to date. The tree fern is widespread in lowland Amazonian forests, from Mexico to Panama, Peru, Bolivia and northern Brazil [1,2]. Especially in Costa Rica, its rhizome is used in ethnic medicine to treat intestinal diseases [3]. Considering the interest in natural compounds that mostly originates from traditional use and documentation, numerous 
valuable anticancer drugs have ultimately been obtained from plants [4-7]. Prenylated xanthones have gained a lot of interest during the last decade, as they are well known for their cytotoxic effects on malignant cells. The best studied among these are the mangostins that induce cell cycle arrest and active cell death in a broad range of tumor cells [8-10]. After establishing cytotoxic activity of fractions from an aqueous and a methanolic extract of $M$. rostrata against colorectal cancer (CRC) cells [3], an activity-guided study led to the isolation of structurally related 2-deprenyl-rheediaxanthone $B(X B)$ and 2-deprenyl-7-hydroxy-rheediaxanthone B (OH-XB). These studies identified the two compounds as biologically highly active, blocking cell cycle progression and inducing cell death in CRC cells $[3,11]$. More recently, our findings suggested that both substances also interact with the cellular targets forkhead box protein M1 (FoxM1) and topoisomerase I (topo I) [12]. Thus, we observed that XB was a strong inducer of FoxM1 degradation, while OH-XB had a stronger impact on topo I activity. Based on these results, the focus of the current study was the isolation of further closely related xanthones in order to explore the efficacy and cellular targets in SW480 CRC cells in order to establish a detailed structure-activity relationship.

\section{Results and Discussion}

A detailed investigation of a $\mathrm{CH}_{2} \mathrm{Cl}_{2}$ extract of the dried rootlets from $M$. rostrata resulted in the isolation of three xanthones $(\mathbf{1}, \mathbf{2}, \mathbf{3})$, and of an additional compound (4), which was only accessible as a mixture (M) together with $\mathbf{1}$ (Figure 1). They are all new, natural compounds and were identified by chromatographic, spectrometric and spectroscopic methods. This led to the elucidation of 2-deprenyl-6-O-methyl-7-hydroxy-rheediaxanthone B (1) as well as 2-deprenyl-5-Omethyl-7-methoxy-rheediaxanthone B (2). Compound 3 was identified as 2-deprenyl-5-O-methyl-7hydroxy-rheediaxanthone B. In the mixture, together with 1, compound 4 was identified as 2-deprenyl7-methoxy-rheediaxanthone $B$ at a ratio of 1:0.3, according to the integration in the ${ }^{1} \mathrm{H}-\mathrm{NMR}$.

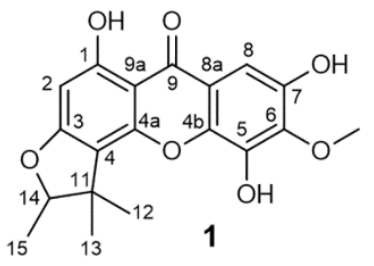<smiles>COc1cc2c(=O)c3c(O)cc4c(c3oc2c(OC)c1O)C(C)(C)C(C)O4</smiles><smiles>COc1c(O)c(O)cc2c(=O)c3c(O)cc4c(c3oc12)C(C)(C)C(C)O4</smiles><smiles>COc1cc2c(=O)c3c(O)cc4c(c3oc2c(O)c1O)C(C)(C)C(C)O4</smiles>

Figure 1. Chemical structures of the identified xanthones.

In general, the ${ }^{1} \mathrm{H}$ - and ${ }^{13} \mathrm{C}$-NMR spectra are very similar to published data for 2-deprenylrheediaxanthone B [3]. For the prenyl part in all substances, the ${ }^{1} \mathrm{H}-\mathrm{NMR}$ spectra show two singlets at 1.33 and $1.62 \mathrm{ppm}$ (two $\mathrm{CH}_{3}$ ), and one doublet at $1.41 \mathrm{ppm}\left(\mathrm{CH}_{3}\right)$ coupled to a quartet at $4.54 \mathrm{ppm}$ $(\mathrm{CH})$, all within a shift range of $\pm 0.015 \mathrm{ppm}$. In the aromatic region, proton 2 is detected around $6.13 \mathrm{ppm}( \pm 0.014 \mathrm{ppm})$. The second aromatic signal for $\mathrm{H}-8$ is in the range from 7.08 to $7.36 \mathrm{ppm}$, influenced by the different methylation patterns. As only these two aromatic protons are present, the second aromatic ring has to carry three phenolic groups, i.e., either one being methylated or two in compound 2. These methyl groups can be seen at around $3.95 \mathrm{ppm}$. In the ${ }^{13} \mathrm{C}-\mathrm{NMR}$ spectra, the signals for the prenyl part and the connected aromatic ring match very closely. To elucidate the 
substitution pattern, HMBC and NOESY spectra were recorded. In the HMBC spectra, the methyl protons give a three-bond correlation to the quaternary aromatic carbon, where the methoxy group is located. Methoxy substitution at position 6 or 7 shows a correlation to this carbon starting from $\mathrm{H}-8$, either via three or two bonds, respectively. On the other hand, a methoxy group at position 7 gives a correlation in the NOESY spectrum to $\mathrm{H}-8$, and in the case of a substitution at $\mathrm{C}-5$, a minute cross peak can be seen in methyl groups 12 and 13 (Tables 1-3).

Table 1. ${ }^{1} \mathrm{H}$ - and ${ }^{13} \mathrm{C}-\mathrm{NMR}$ data of mixture $\mathbf{M}$ in $\mathrm{CD}_{3} \mathrm{OD}$.

\begin{tabular}{|c|c|c|c|c|c|c|c|c|c|}
\hline \multicolumn{5}{|c|}{ Mixture M Compound 1} & \multicolumn{5}{|c|}{ Mixture M Compound 4} \\
\hline $\begin{array}{l}\text { Atom } \\
\text { Position }\end{array}$ & & $\begin{array}{c}{ }^{1} \mathbf{H} \\
\text { (ppm) }\end{array}$ & $\begin{array}{l}J_{\text {H.H }} \\
(\mathrm{Hz})\end{array}$ & $\begin{array}{c}{ }^{13} \mathrm{C} \\
\text { (ppm) }\end{array}$ & $\begin{array}{c}\text { Atom } \\
\text { Position }\end{array}$ & & $\begin{array}{c}{ }^{1} \mathbf{H} \\
\text { (ppm) }\end{array}$ & $\begin{array}{l}J_{\text {H.H }} \\
(\mathrm{Hz})\end{array}$ & $\begin{array}{c}{ }^{13} \mathrm{C} \\
\text { (ppm) }\end{array}$ \\
\hline 1 & C & - & - & 165.13 & 1 & C & - & - & 164.96 \\
\hline 2 & $\mathrm{CH}$ & 6.120 & $\mathrm{~s}$ & 93.99 & 2 & $\mathrm{CH}$ & 6.118 & $\mathrm{~s}$ & 93.98 \\
\hline 3 & $\mathrm{C}$ & - & - & 167.27 & 3 & $\mathrm{C}$ & - & - & 166.94 \\
\hline 4 & $\mathrm{C}$ & - & - & 114.12 & 4 & $\mathrm{C}$ & - & - & 114.13 \\
\hline $4 a$ & $\mathrm{C}$ & - & - & 154.44 & $4 a$ & $\mathrm{C}$ & - & - & 154.30 \\
\hline $4 b$ & $\mathrm{C}$ & - & - & 148.90 & $4 \mathrm{~b}$ & C & - & - & $\begin{array}{c}\mathrm{e}^{1} \\
143.66\end{array}$ \\
\hline 5 & C & - & - & 140.89 & 5 & C & - & - & 134.94 \\
\hline 6 & $\begin{array}{c}\mathrm{C} \\
\mathrm{OCH}_{3}\end{array}$ & $\begin{array}{c}- \\
3.966\end{array}$ & $\mathrm{~s}$ & $\begin{array}{c}143.47 \\
61.19\end{array}$ & 6 & $\mathrm{C}$ & - & $\mathrm{s}$ & e 143.69 \\
\hline 7 & C & - & - & 141.83 & 7 & $\begin{array}{c}\mathrm{C} \\
\mathrm{OCH}_{3}\end{array}$ & $\begin{array}{c}- \\
3.948\end{array}$ & $\mathrm{~s}$ & $\begin{array}{c}147.27 \\
56.58\end{array}$ \\
\hline 8 & $\mathrm{CH}$ & 7.083 & $\mathrm{~s}$ & 100.46 & 8 & $\mathrm{CH}$ & 7.170 & $\mathrm{~s}$ & 96.47 \\
\hline $8 a$ & C & - & - & 117.60 & $8 a$ & $C$ & & - & 112.93 \\
\hline 9 & C & - & - & 181.70 & 9 & C & - & - & 181.50 \\
\hline $9 a$ & C & - & - & 104.28 & $9 a$ & C & - & - & 104.08 \\
\hline 11 & C & - & - & 44.95 & 11 & C & - & - & 44.98 \\
\hline 12 & $\mathrm{CH}_{3}$ & 1.604 & $\mathrm{~s}$ & 25.92 & 12 & $\mathrm{CH}_{3}$ & 1.611 & $\mathrm{~s}$ & 25.95 \\
\hline 13 & $\mathrm{CH}_{3}$ & 1.316 & $\mathrm{~s}$ & 21.39 & 13 & $\mathrm{CH}_{3}$ & 1.320 & $\mathrm{~s}$ & 21.42 \\
\hline 14 & $\mathrm{CH}$ & 4.530 & q 6.6 & 92.28 & 14 & $\mathrm{CH}$ & 4.525 & q 6.6 & 92.21 \\
\hline 15 & $\mathrm{CH}_{3}$ & 1.398 & q 6.6 & 14.56 & 15 & $\mathrm{CH}_{3}$ & 1.399 & q 6.6 & 14.56 \\
\hline
\end{tabular}

Table 2. ${ }^{1} \mathrm{H}$ - and ${ }^{13} \mathrm{C}-\mathrm{NMR}$ data of compound $\mathbf{1}$ and 2 in $\mathrm{CD}_{3} \mathrm{OD}$.

\begin{tabular}{|c|c|c|c|c|c|c|c|c|c|}
\hline \multicolumn{5}{|c|}{ Compound 1} & \multicolumn{5}{|c|}{ Compound 2} \\
\hline $\begin{array}{l}\text { Atom } \\
\text { Position }\end{array}$ & & $\begin{array}{c}{ }^{1} \mathbf{H} \\
(\mathrm{ppm})\end{array}$ & $\begin{array}{l}J_{\mathrm{H} . \mathrm{H}} \\
(\mathrm{Hz})\end{array}$ & $\begin{array}{c}{ }^{13} \mathrm{C} \\
\text { (ppm) }\end{array}$ & $\begin{array}{l}\text { Atom } \\
\text { Position }\end{array}$ & & $\begin{array}{c}{ }^{1} \mathbf{H} \\
\text { (ppm) }\end{array}$ & $\begin{array}{l}J_{\mathrm{H} . \mathrm{H}} \\
(\mathrm{Hz})\end{array}$ & $\begin{array}{c}{ }^{13} \mathrm{C} \\
\text { (ppm) }\end{array}$ \\
\hline 1 & C & - & - & 165.16 & 1 & C & - & - & 164.98 \\
\hline 2 & $\mathrm{CH}$ & 6.139 & $\mathrm{~s}$ & 93.99 & 2 & $\mathrm{CH}$ & 6.145 & $\mathrm{~s}$ & 94.20 \\
\hline 3 & C & - & - & 167.30 & 3 & $\mathrm{C}$ & - & - & 166.92 \\
\hline 4 & C & - & - & 114.14 & 4 & C & - & - & 114.10 \\
\hline $4 a$ & $\mathrm{C}$ & - & - & 154.47 & $4 a$ & $\mathrm{C}$ & - & - & 154.08 \\
\hline $4 \mathrm{~b}$ & $\mathrm{C}$ & - & - & 148.94 & $4 b$ & $\mathrm{C}$ & - & - & 147.98 \\
\hline 5 & $\mathrm{C}$ & - & - & 141.00 & 5 & $\stackrel{\mathrm{C}}{\mathrm{OCH}_{3}}$ & $\begin{array}{c}- \\
3.969\end{array}$ & s & $\begin{array}{c}136.75 \\
61.76\end{array}$ \\
\hline 6 & $\begin{array}{c}\mathrm{C} \\
\mathrm{OCH}_{3}\end{array}$ & $\begin{array}{c}- \\
3.967\end{array}$ & $\begin{array}{l}- \\
\mathrm{s}\end{array}$ & $\begin{array}{c}143.52 \\
61.18\end{array}$ & 6 & $\mathrm{C}$ & - & - & 151.97 \\
\hline 7 & C & - & - & 141.89 & 7 & $\begin{array}{c}\mathrm{C} \\
\mathrm{OCH}_{3}\end{array}$ & $\begin{array}{c}- \\
3.944\end{array}$ & $\begin{array}{l}- \\
s\end{array}$ & $\begin{array}{c}148.76 \\
56.59\end{array}$ \\
\hline 8 & $\mathrm{CH}$ & 7.090 & $\mathrm{~s}$ & 100.39 & 8 & $\mathrm{CH}$ & 7.359 & s & 100.67 \\
\hline $8 a$ & $\mathrm{C}$ & - & - & 117.62 & $8 \mathrm{a}$ & $\mathrm{C}$ & - & - & 111.67 \\
\hline 9 & $\mathrm{C}$ & - & - & 181.75 & 9 & $\mathrm{C}$ & - & - & 180.93 \\
\hline $9 a$ & $\mathrm{C}$ & - & - & 104.30 & $9 a$ & $\mathrm{C}$ & - & - & 104.07 \\
\hline 11 & $\mathrm{C}$ & - & - & 44.97 & 11 & $\mathrm{C}$ & - & - & 44.97 \\
\hline 12 & $\mathrm{CH}_{3}$ & 1.613 & $\mathrm{~s}$ & 25.95 & 12 & $\mathrm{CH}_{3}$ & 1.626 & s & 26.12 \\
\hline 13 & $\mathrm{CH}_{3}$ & 1.327 & $\mathrm{~s}$ & 21.39 & 13 & $\mathrm{CH}_{3}$ & 1.338 & $\mathrm{~s}$ & 21.72 \\
\hline 14 & $\mathrm{CH}$ & 4.547 & q 6.6 & 92.31 & 14 & $\mathrm{CH}$ & 4.555 & q 6.6 & 92.13 \\
\hline 15 & $\mathrm{CH}_{3}$ & 1.407 & d 6.6 & 14.58 & 15 & $\mathrm{CH}_{3}$ & 1.417 & d 6.6 & 14.53 \\
\hline
\end{tabular}


Table 3. ${ }^{1} \mathrm{H}$ - and ${ }^{13} \mathrm{C}-\mathrm{NMR}$ data of compound 3 in $\mathrm{CD}_{3} \mathrm{OD}$.

\begin{tabular}{|c|c|c|c|c|}
\hline \multicolumn{5}{|c|}{ Compound 3} \\
\hline Atom Position & & ${ }^{1} \mathrm{H}(\mathrm{ppm})$ & $J_{\text {H.H }}(\mathrm{Hz})$ & ${ }^{13} \mathrm{C}$ (ppm) \\
\hline 1 & $\mathrm{C}$ & - & - & 164.95 \\
\hline 2 & $\mathrm{CH}$ & 6.117 & $\mathrm{~s}$ & 93.99 \\
\hline 3 & $\mathrm{C}$ & - & - & 166.74 \\
\hline 4 & $\mathrm{C}$ & - & - & 113.93 \\
\hline $4 a$ & $\mathrm{C}$ & - & - & 154.11 \\
\hline $4 b$ & $\mathrm{C}$ & - & - & 148.34 \\
\hline & C & - & - & 136.60 \\
\hline 5 & $\mathrm{OCH}_{3}$ & 3.954 & $\mathrm{~s}$ & 61.78 \\
\hline 6 & C & - & - & $u^{1} 139.09$ \\
\hline 7 & $\mathrm{C}$ & - & - & u 141.84 \\
\hline 8 & $\mathrm{CH}$ & 7.224 & $\mathrm{~s}, \mathrm{br}$ & 102.75 \\
\hline $8 a$ & $\mathrm{C}$ & - & - & u 114.79 \\
\hline 9 & $\mathrm{C}$ & - & - & 181.23 \\
\hline $9 a$ & $\mathrm{C}$ & - & - & 104.05 \\
\hline 11 & $\mathrm{C}$ & - & - & 44.96 \\
\hline 12 & $\mathrm{CH}_{3}$ & 1.624 & $\mathrm{~s}$ & 26.14 \\
\hline 13 & $\mathrm{CH}_{3}$ & 1.332 & $\mathrm{~s}$ & 21.72 \\
\hline 14 & $\mathrm{CH}$ & 4.536 & q 6.6 & 92.05 \\
\hline 15 & $\mathrm{CH}_{3}$ & 1.410 & d 6.6 & 14.52 \\
\hline
\end{tabular}

The identity, as determined by NMR, was further confirmed by LC-HRMS (see Section 3. General experimental procedures). Mixture $\mathbf{M}$ had a molecular formula of $\mathrm{C}_{19} \mathrm{H}_{18} \mathrm{O}_{7}$, as revealed by the ${ }^{13} \mathrm{C}$-NMR data and a protonated ion $[\mathrm{M}+\mathrm{H}]^{+}$at $\mathrm{m} / \mathrm{z} 359.1138$ (calcd. for $\mathrm{C}_{19} \mathrm{H}_{19} \mathrm{O}_{7}, 359.1131$ ) in the positive HRMS, proving that compounds 1 and 4 are regioisomeres. HRMS analyses revealed a quasimolecular ion $[\mathrm{M}+\mathrm{H}]^{+}$at $m / z 359.1137$ for compound $\mathbf{1}$ and at $m / z 359.1132$ for compound 3, suggesting a molecular formula of $\mathrm{C}_{19} \mathrm{H}_{18} \mathrm{O}_{7}$ in conjunction with the ${ }^{13} \mathrm{C}-\mathrm{NMR}$ data (both calcd. for $\mathrm{C}_{19} \mathrm{H}_{19} \mathrm{O}_{7}, 359.1131$ ); thus, 3 is a third possible monomethylated regioisomer. For compound 2, a molecular formula of $\mathrm{C}_{20} \mathrm{H}_{20} \mathrm{O}_{7}$ was assigned from its ${ }^{13} \mathrm{C}-\mathrm{NMR}$ data, and positive HRMS showed a quasimolecular ion $[\mathrm{M}+\mathrm{H}]^{+}$at $m / z 373.1296$ (calcd. for $\mathrm{C}_{20} \mathrm{H}_{21} \mathrm{O}_{7}, 373.1290$ ), confirming the additional methyl group.

Due to sufficient purity, mixture $\mathbf{M}$ as well as compounds $\mathbf{1}$ and $\mathbf{2}$ could be evaluated in biological tests. For this purpose, $\mathbf{M}, \mathbf{1}$ and $\mathbf{2}$, as well as $\mathrm{XB}$ and $\mathrm{OH}-\mathrm{XB}$ were dissolved in DMSO and diluted into the medium of semiconfluent SW480 CRC cells, which had shown the highest sensitivity to prenylated xanthones in our previous studies [3,12]. Cytotoxicity was determined by neutral red uptake and MTT assays after $48 \mathrm{~h}$ (Figure 2A). Based on the small amounts of compounds available and the consideration that a candidate drug should be effective at concentrations below $10 \mu \mathrm{M}, 12 \mu \mathrm{M}$ was the highest concentration tested for each compound in the viability tests. At that concentration, specific activity was $15 \%$ and $16 \%$ for $\mathrm{OH}-\mathrm{XB}$ and $\mathrm{XB}$ respectively, while it was $49 \%$ and $54 \%$ for $\mathbf{1}$ and $\mathbf{M}$, and $84 \%$ in cultures exposed to 2 , indicating that all three new compounds were less effective than $\mathrm{XB}$ and $\mathrm{OH}-\mathrm{XB} . \mathrm{IC}_{50}$ concentrations for the novel xanthones could not be determined, because the curves did not reach a bottom level. However, comparisons of the dose-response curves by two-way ANOVA demonstrated statistically significant differences between the methylated compounds and $\mathrm{XB}$, as well as $\mathrm{OH}-\mathrm{XB}$, as shown in Table 4, that lists cytotoxic activity as defined by the extent of cell loss in the exposed culture. With this limitation, it was possible to draw two conclusions regarding the methylated compounds: (1) there were no differences between the effects of $\mathbf{M}$ and $\mathbf{1}$ at any concentration. As $\mathbf{M}$ consists of $\mathbf{1}$ with about 25\% $\mathbf{4}, \mathbf{4}$ and $\mathbf{1}$ seem to have similar activity. (2) Dimethylation in compound $\mathbf{2}$ strongly reduced the cytotoxic effect. 
A

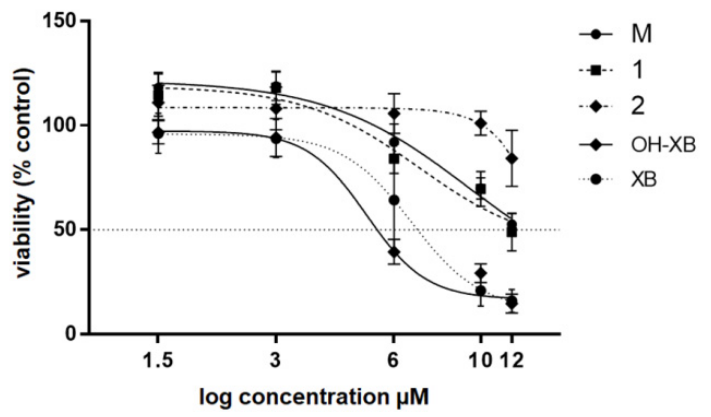

B

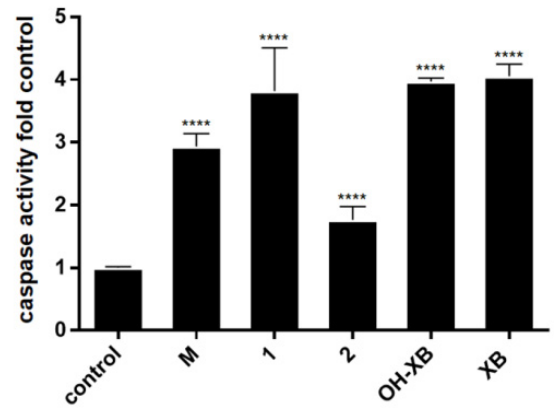

Figure 2. Cytotoxicity and caspase activity (A) Semiconfluent cultures of SW480 were exposed to the indicated concentrations of $\mathbf{M}, \mathbf{1}, \mathbf{2}, \mathrm{OH}-\mathrm{XB}$ and XB. Viability was determined after $48 \mathrm{~h}$ by neutral red uptake assay and MTT assay. The results are the mean \pm SD pooled from four independent experiments $(n=4)$ performed in five-fold measurements. $\mathbf{M}, \mathbf{1}$, and $\mathbf{2}$ were less active than $\mathrm{XB}$ and $\mathrm{OH}-\mathrm{XB}$ at $p<0.0001$ according to two-way ANOVA of Data. (B) Protein lysates were harvested $48 \mathrm{~h}$ after exposure to $15 \mu \mathrm{M}$ of $\mathbf{M}, \mathbf{1}, \mathbf{2}, \mathrm{OH}-\mathrm{XB}$ and $\mathrm{XB}$ and prepared to measure caspase activity. The results are the mean \pm SD pooled from three independent experiments $(n=3)$ performed in duplicate. ${ }^{* * * *}$ indicates a significant difference from control at $p<0.0001$.

Table 4. Sensitivity of SW480 cells to $\mathbf{M}, \mathbf{1}, \mathbf{2}, \mathrm{OH}-\mathrm{XB}$ and XB.

\begin{tabular}{ccc}
\hline & \% Cytotoxic Activity $(\mathbf{1 2} \boldsymbol{\mu M})$ & SD \\
\hline $\mathbf{M}$ & 46.04 & \pm 3.34 \\
$\mathbf{1}$ & 51.04 & \pm 6.00 \\
$\mathbf{2}$ & 15.79 & \pm 13.45 \\
OH-XB & 85.32 & \pm 4.53 \\
XB & 83.99 & \pm 5.44 \\
\hline
\end{tabular}

Induction of apoptosis was tested by induction of caspase activity using a standard enzyme assay with the substrate Ac-DEVD-APC, as shown in our previous studies [11,12]. After exposure to $15 \mu \mathrm{M}$ of $\mathbf{M}, 1,2, \mathrm{OH}-\mathrm{XB}$ and $\mathrm{XB}$ for $48 \mathrm{~h}$, we found a significant activation of caspase compared to control (Figure 2B). All prenylated xanthones induced caspase activity with $\mathbf{M}$ and $\mathbf{1}$ reaching similar levels as $\mathrm{XB}$ and $\mathrm{OH}-\mathrm{XB}$. Activation by compound 2 was significantly less compared to those by the other compounds, in line with the difference in cytotoxic activity. This indicates that the mode of action of the compounds involves the activation of caspase-dependent cell death.

Cytotoxic activity and induction of active cell death is a common effect of plant-derived xanthones [13]. The best studied compound in this category is $\alpha$-mangostin, that has been shown to induce cell cycle arrest and apoptosis in several malignant cell lines [10,14,15]. Our own previous studies described similar effects for $\mathrm{XB}$ and $\mathrm{OH}-\mathrm{XB}[3,11,12]$. To evaluate the cellular mechanisms triggered by the new xanthones, cellular targets established in previous work $[3,11,12]$ were studied. Specifically, FoxM1, as well as the mitotic cyclins A and B [16], were analyzed by western blotting.

Loss of the cellular target FoxM1 was identified as a common effect of $\mathrm{OH}-\mathrm{XB}$ and $\mathrm{XB}$ [11]. This effect was obtained by a combination of inhibited gene expression on the mRNA level and active degradation of the protein [12]. The FoxM1 transcription factor is essential for the execution of mitosis, upregulated in many malignancies, and plays a key role in oncogenesis [17-20]. The new methylated compounds reduced FoxM1 levels after $48 \mathrm{~h}$ of treatment. This effect was not only observed with $\mathbf{M}$ and $\mathbf{1}$, but also with $\mathbf{2}$. This is the only strong effect induced by $\mathbf{2}$, and needs further analysis, as it may be related to alterations in the malignant characteristics of the treated cells [17]. The xanthone mangiferin has been reported to modulate epithelial-mesenchymal transition [21], an effect that may well be mediated by FoxM1 [22]. However, for this purpose, new plant material has to be extracted, as in this study, the required amounts of compounds $\mathbf{1}$ and $\mathbf{2}$ were not available for further functional assays. 
Cyclins A and B are the main mitotic cyclins and are both required for viability, as shown by experiments with knockout mice [16]. Determination of their protein level was used as a compound-sparing way of cell cycle analysis (Figure 3). Cyclin B was significantly upregulated with $\mathbf{M}$ and 1, indicating that cells accumulate in the G2/M-phase after treatment. The results for cyclin $\mathrm{A}$, an indicator for early mitotic events, were similar but less pronounced: protein abundance was increased by about $50 \%$ after treatment with $\mathbf{M}$ and $\mathbf{1}$. In our recent analysis of $\mathrm{XB}$ and $\mathrm{OH}-\mathrm{XB}$, a comparable increase of cyclins A and B was only observed in XB-exposed cultures; this was correlated with cell cycle arrest in $\mathrm{G} 2 / \mathrm{M}$. After treatment with $\mathrm{OH}-\mathrm{XB}$, cyclin A was downregulated and cyclin B strongly decreased, which was also reflected by a cell cycle arrest in the S-phase but not in G2/M [11]. In cells exposed to compound 2, neither an increase nor a decrease in the mitotic cyclins was observed, suggesting that cell cycle distribution was not altered. This is in line with the known low cytotoxic activity of the dimethylated xanthone.

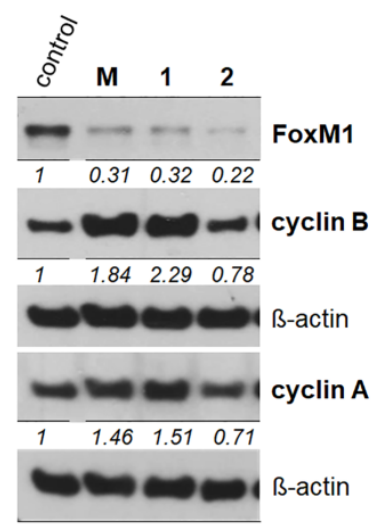

Figure 3. Cell cycle-related proteins. Protein lysates of SW480 cells were harvested after $48 \mathrm{~h}$ of exposure to $15 \mu \mathrm{M}$ M, 1 and 2, and the protein levels of FoxM1, cyclin B and cyclin A were analyzed by western blotting. The numbers below the bands give the mean fold increase of three independent experiments ( $n=3$, control set to $ß$-actin).

The second cellular activity that has been previously described specifically for $\mathrm{OH}-\mathrm{XB}$ was the inhibition of topo I [12]. Therefore, we evaluated the impact of $\mathbf{M}, \mathbf{1}$ and $\mathbf{2}$ on topo I activity in comparison to the positive control camptothecin (CPT), as well as to $\mathrm{XB}$ and $\mathrm{OH}-\mathrm{XB}$ (Figure 4), by a DNA relaxation assay. Topo I inhibition by $\mathrm{XB}$ and the dimethylated compound $\mathbf{2}$ showed a low amount of restored supercoiled DNA. In contrast, mixture $\mathbf{M}$ and compound $\mathbf{1}$ produced a drastic inhibitory effect after treatment at a concentration of $100 \mu \mathrm{M}$. However, no inhibition was detected at $10 \mu \mathrm{M}$. Only OH-XB distinctly inhibited topo I at both concentrations, i.e., 10 and $100 \mu \mathrm{M}$.

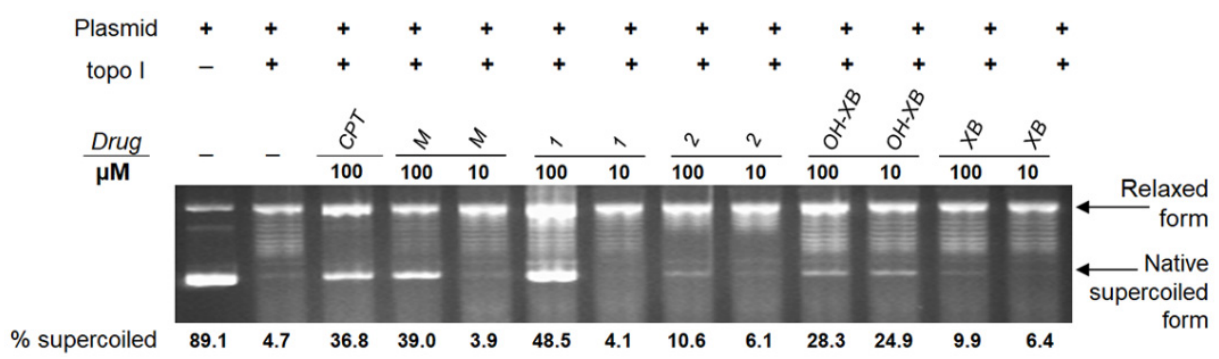

Figure 4. Inhibition of topoisomerase I. First, $250 \mathrm{ng}$ plasmid DNA (pGEM1) was incubated with $10 \mu \mathrm{M}$ and $100 \mu \mathrm{M}$ of $\mathbf{M}, \mathbf{1}, \mathbf{2}, \mathrm{OH}-\mathrm{XB}$ and $\mathrm{XB}$ containing $2 \mu \mathrm{L}$ topo I. The percentage of supercoiled DNA was then determined by the ratio of supercoiled to relaxed DNA. The numbers below the bands give the mean fold increase of three independent experiments $(n=3)$. 


\section{Materials and Methods}

\subsection{General Experimental Procedures}

Column chromatography was performed on Sephadex LH-20 under elution with $\mathrm{MeOH} \mathrm{50 \%} \mathrm{to}$ $80 \%$ (column diameter and height: $1 \mathrm{~cm}$ and $30 \mathrm{~cm}$ ). For TLC silica gel plates (Merck, Darmstadt, Germany) and the mobile phases (1) toluene-ethyl formate-HCOOH (10:4:1); (2) EtOAc-HCOOH$\mathrm{MeOH}-\mathrm{H}_{2} \mathrm{O}$ (70:8:8:11); (3) EtOAc-HCOOH-MeOH-H${ }_{2} \mathrm{O}$ (70:8:4:4) were used; detection: $\mathrm{UV}_{254 \mathrm{~nm}}$; anisaldehyde- $\mathrm{H}_{2} \mathrm{SO}_{4}$-reagent; Naturstoff-reagent A/PEG 400 under $\mathrm{UV}_{366 \mathrm{~nm}}$.

For LC-HRMS analyses, the Ultimate 3000 UHPLC system (Thermo Fisher Scientific, San Jose, CA, USA) was equipped with a reversed-phase C18 column (Kinetex; $2.1 \mathrm{~mm} \times 15 \mathrm{~cm}, 2.6 \mu \mathrm{m}, \mathrm{C} 18$ $100 \AA$ ). Mobile phases were A) $\mathrm{H}_{2} \mathrm{O}-\mathrm{HCOOH}(100: 0.02)(v / v)$ and B) ACN-MeOH-HCOOH (80:20:0.02) $(v / v)$. A $10 \mathrm{~min}$ binary gradient with flow rate set to $250 \mu \mathrm{L} / \mathrm{min}$ was applied as follows: $0-1 \mathrm{~min}, 5 \% \mathrm{~B}$; 2-6 min, 5-85\% B; 6-8 min, 95\% B; 8-10 min re-equilibration with 5\% B). $5 \mu \mathrm{L}$ of each sample $(1 \mathrm{mg} / \mathrm{mL})$ were injected. Mass spectrometric detection was performed with an ESI-Qq-TOF mass spectrometer (micrOTOF-Q II, maXis HD, Bruker Compass, Bremen, Germany), $200{ }^{\circ} \mathrm{C}$ heater temperature, $4 \mathrm{~L} / \mathrm{min}$ drying gas and 0.4 bar nebulizer gas. $2.0 \mathrm{KV}$ spray voltage at $250{ }^{\circ} \mathrm{C}$ capillary temperature were applied to achieve negative/positive ion mode ionization. MS1 scans were performed with an $\mathrm{m} / \mathrm{z}$ range from 150 to 1500 . MS/MS scans of the most abundant ions were achieved through high collisional dissociation (HCD) fragmentation at $55.0 \mathrm{eV}$ normalized collision energy.

All NMR spectra were recorded on a Bruker Avance III HD 700 NMR spectrometer (Bruker BioSpin, Rheinstetten, Germany) using a $5 \mathrm{~mm}$ helium cooled cryo probe (QCI-F) with z axis gradients and automatic tuning and matching accessory. The resonance frequency for ${ }^{1} \mathrm{H}-\mathrm{NMR}$ was $700.40 \mathrm{MHz}$, for ${ }^{13} \mathrm{C}-\mathrm{NMR} 176.12 \mathrm{MHz}$. All measurements were performed for a solution in fully deuterated methanol at a temperature of $298 \mathrm{~K}$. Standard 1D, like ${ }^{13} \mathrm{C}-\mathrm{DEPTQ}$, and gradient-enhanced (ge) 2D experiments, like double quantum filtered (DQF) COSY, TOCSY, NOESY (mixing time 800 ms), HSQC, and HMBC (long range J coupling $8 \mathrm{~Hz}$ ), were used as supplied by the manufacturer. Chemical shifts are referenced internally to the residual, nondeuterated solvent signal for ${ }^{1} \mathrm{H}(\delta=3.31$ ppm) or to the carbon signal of the solvent for ${ }^{13} \mathrm{C}(\delta=49.00 \mathrm{ppm})$.

\subsection{Chemicals and Reagents}

All solvents were analytical-grade or HPLC-grade. ACN (Chromanorm), EtOAc (Normapur) and $\mathrm{MeOH}$ (LiChrosolv) were obtained from VWR International (Radnor, Pennsylvania, PA, USA). Toluene and ethylformate were acquired from Merck KGaA (Darmstadt, Germany). HCOOH was obtained from Carl Roth GmbH (Karlsruhe, Germany).

\subsection{Plant Material}

Underground parts of Metaxya rostrata were collected in February 2003 in La Gamba, Costa Rica and authenticated in the Herbarium of the Museo National in San Jose by Dr. W. Huber (University of Vienna). Voucher specimens are deposited under the number MR0203 at the Herbarium of the Department of Pharmacognosy, University of Vienna, Austria.

\subsection{Extraction and Isolation}

The dried rootlets of $M$. rostrata $\left(920 \mathrm{~g}\right.$ ) were extracted by sonification with $\mathrm{CH}_{2} \mathrm{Cl}_{2}$, resulting in $5.3 \mathrm{~g} \mathrm{CH}_{2} \mathrm{Cl}_{2}$ extract which was separated by column chromatography on Sephadex LH-20 under elution with EtOAc. Two hundred and ninety fractions were pooled to obtain 16 subfractions (CC-13/1 to CC-13/16) [23]. The most active subfractions were eluted sequentially by solid phase extraction (SPE) using four reservoir volumes of $60 \%, 70 \%, 80 \%, 90 \%$ and 100\% $\mathrm{MeOH}$ [3,23]. Fractions CC-13/9 to CC-13/11 were pooled and eluted with $80 \% \mathrm{MeOH}$, resulting in fraction SPE-9-11/80\%. Fraction CC-13/6 was eluted with $80 \% \mathrm{MeOH}$ resulting in fraction SPE-6/80\% and fraction CC-13/7 was eluted with $60 \% \mathrm{MeOH}$, resulting in fraction SPE-13/60\%. 
Fraction SPE-9-11/80\% (10.2 mg), as well as SPE-13/60\% (5.7 mg) and SPE-6/80\% (7.7 mg), were further analyzed by TLC and LC-MS. SPE-9-11/80\% was subjected to column chromatography (CC1) on Sephadex LH-20 $(1 \times 30 \mathrm{~cm} ; 2 \mathrm{~mL} / 10 \mathrm{~min}$; eluent $50 \% \mathrm{MeOH})$ to obtain 11 subfractions, resulting in the isolation of mixture $\mathrm{M}(8 \mathrm{mg}$, purity $>95 \%)$, at a ratio of $1: 0.3$. Fractionation of SPE- $13 / 60 \%$ by CC 2 on Sephadex LH-20 ( $1 \times 30 \mathrm{~cm} ; 1 \mathrm{~mL} / 10 \mathrm{~min}$; eluent 50 to $80 \% \mathrm{MeOH} ; 14$ subfractions $)$ yielded compounds $1(2.85 \mathrm{mg}$, purity $>98 \%)$ and $3(1.28 \mathrm{mg}$, purity $>50 \%)$. Compound $2(0.7 \mathrm{mg}$; purity $>96 \%)$ was obtained from fraction SPE-6/80\% in the same way, by CC3 (Sephadex LH-20; $1 \times 30 \mathrm{~cm} ; 1 \mathrm{~mL} / 10 \mathrm{~min}$; eluent $50 \% \mathrm{MeOH} ; 10$ subfractions).

2-Deprenyl-6-O-methyl-7-hydroxy-rheediaxanthone B (1), 2-deprenyl-7-methoxy-rheediaxanthone B (4) [ratio 1:0.3] (M), yellow needles, ${ }^{1} \mathrm{H}-\mathrm{NMR}\left(700.40 \mathrm{MHz}, \mathrm{CD}_{3} \mathrm{OD}\right)$ and ${ }^{13} \mathrm{C}-\mathrm{NMR}\left(176.12 \mathrm{MHz}, \mathrm{CD}_{3} \mathrm{OD}\right)$ data: see Table 1; HRMS m/z $359.1138[\mathrm{M}+\mathrm{H}]^{+}$(calcd. for $\mathrm{C}_{19} \mathrm{H}_{19} \mathrm{O}_{7}, 359.1131$ ); see also Supplementary Figures S1-S8.

2-Deprenyl-6-O-methyl-7-hydroxy-rheediaxanthone $B(\mathbf{1})$, yellow microcrystalline powder, ${ }^{1} \mathrm{H}-\mathrm{NMR}$ $\left(700.40 \mathrm{MHz}, \mathrm{CD}_{3} \mathrm{OD}\right)$ and ${ }^{13} \mathrm{C}-\mathrm{NMR}\left(176.12 \mathrm{MHz}, \mathrm{CD}_{3} \mathrm{OD}\right.$ ) data: see Table 1; HRMS m/z 359.1137 $[\mathrm{M}+\mathrm{H}]^{+}$(calcd. for $\mathrm{C}_{19} \mathrm{H}_{19} \mathrm{O}_{7}, 359.1131$ ); see also Supplementary Figures S9-S16.

2-Deprenyl-5-O-methyl-7-methoxy-rheediaxanthone $B$ (2), yellowish amorphous powder, ${ }^{1} \mathrm{H}-\mathrm{NMR}$ (700.40 MHz, $\left.\mathrm{CD}_{3} \mathrm{OD}\right)$ and ${ }^{13} \mathrm{C}-\mathrm{NMR}\left(176.12 \mathrm{MHz}, \mathrm{CD}_{3} \mathrm{OD}\right)$ data: see Table 2; HRMS m/z 373.1296 $[\mathrm{M}+\mathrm{H}]^{+}$(calcd. for $\mathrm{C}_{20} \mathrm{H}_{21} \mathrm{O}_{7}, 373.1290$ ); see also Supplementary Figures S17-S24.

2-Deprenyl-5-O-methyl-7-hydroxy-rheediaxanthone $B(3)$, pale yellowish amorphous powder, ${ }^{1} \mathrm{H}$-NMR (700.40 MHz, $\mathrm{CD}_{3} \mathrm{OD}$ ) and ${ }^{13} \mathrm{C}-\mathrm{NMR}\left(176.12 \mathrm{MHz}, \mathrm{CD}_{3} \mathrm{OD}\right)$ data: see Table 2; HRMS m/z 359.1132 $[\mathrm{M}+\mathrm{H}]^{+}$(calcd. for $\mathrm{C}_{19} \mathrm{H}_{19} \mathrm{O}_{7}, 359.1131$ ); see also Supplementary Figures S25-S31.

\subsection{Cell Lines}

SW480 CRC cells were obtained from ATCC and kept under standard tissue culture conditions $\left(5 \% \mathrm{CO}_{2}\right.$ at $\left.37^{\circ} \mathrm{C}\right)$ using minimal essential medium (MEM) containing $10 \%$ fetal calf serum (FCS). Cells were regularly checked for Mycoplasma contamination.

\subsection{Cytotoxic Activity}

SW480 cells were plated in 96-well plates at $1 \times 10^{4} /$ well and left to attach for $24 \mathrm{~h}$; semiconfluent cultures were exposed to $\mathbf{M}, \mathbf{1}, 2, \mathrm{OH}-\mathrm{XB}$ and $\mathrm{XB}$ at increasing concentrations $(1.5-12 \mu \mathrm{M})$ for $48 \mathrm{~h}$. Stock solutions of the compounds were prepared in DMSO and stored at $-20^{\circ} \mathrm{C}$. Control media contained the appropriate volume of DMSO with a maximum of $0.12 \%$ in the final solution. Cell viability was determined by neutral red uptake assay or MTT assay as indicated $[3,11]$ and measured at the Tecan infinite 200Pro. Cytotoxic activity was calculated as loss of viability (100-viability).

\subsection{Caspase Activity}

Cells were washed, homogenized in lysis buffer [ $50 \mathrm{mM}$ Tris/ $\mathrm{HCl}$ (pH 7.4), $500 \mathrm{mM} \mathrm{NaCl}, 1 \%$ $\mathrm{NP}-40,0.5 \% \mathrm{Na}-\mathrm{DOC}, 0.1 \% \mathrm{SDS}, 0.05 \% \mathrm{NaN}_{3}, 10 \mathrm{mM} \mathrm{NaF}, 500 \mathrm{mM} o$-vanadate] and supplemented with the protease inhibitor complete [3]. Assessment of caspase activity was performed as reported in [24].

\subsection{Western Blot}

Cells were homogenized using lysis buffer supplemented with complete to block proteolytic enzymes, as well as sodium fluoride and sodium vanadate to inhibit phosphatases [3,11]. Then, $20 \mu \mathrm{g}$ of protein was analyzed by electrophoresis on $12 \%$ polyacrylamide gels and transferred to PVDF blotting membranes (GE Healthcare, Chicago, IL, USA). Primary antibodies used targeted FoxM1 (\#5436, Cell Signaling Technology (CST), Danvers, MA, USA), cyclin A (\#1109, Santa Cruz Biotechnology, Dallas, TX, USA), cyclin B (\#4138, CST) and ß-actin (A5441, Sigma-Aldrich, St. Louis, MO, USA). Detection 
was achieved by HRP-linked secondary antibodies and ECL ${ }^{\mathrm{TM}}$ Prime Western Blotting Detection Reagent (RPN 2236, GE Healthcare) [11].

\subsection{Topoisomerase I Assay}

Topo I activity was investigated as relaxation of supercoiled plasmid DNA (pGEM1) isolated from E. coli. Therefore, $250 \mathrm{ng}$ of plasmid DNA were incubated for $30 \mathrm{~min}$ at $37^{\circ} \mathrm{C}$ with $10 \mu \mathrm{M}$ and $100 \mu \mathrm{M}$ of the test compounds (dissolved in DMSO) in a final volume of $30 \mu \mathrm{L}$, containing $2 \mu \mathrm{L}$ topo I-containing nucleic extract isolated from MCF-7 cells [25], $10 \mathrm{mM}$ Tris (pH 7.9), $100 \mathrm{mM} \mathrm{KCl}, 10 \mathrm{mM} \mathrm{MgCl}_{2}, 0.5 \mathrm{mM}$ dithiothreitol, $0.5 \mathrm{mM}$ ethylenediaminetetraacetic acid, and $0.03 \mathrm{mg} / \mathrm{mL}$ bovine serum albumin (BSA). As a positive control, $100 \mu \mathrm{M}$ camptothecin (CPT) (\#11694, Cayman chemical) was used. The reaction was stopped by incubation with $6 \mu \mathrm{L} 5 \%$ sodium dodecyl sulfate containing $1 \mathrm{mg} / \mathrm{mL}$ proteinase $\mathrm{K}$ at $43^{\circ} \mathrm{C}$ for $30 \mathrm{~min}$. Samples were separated by submarine $1 \%$ agarose gel electrophoresis ( $55 \mathrm{~V}, 2 \mathrm{~h}$ ); gels were stained with $10 \mu \mathrm{L} / 100 \mathrm{~mL}$ ethidium bromide for $20 \mathrm{~min}$. UV-transilluminated gels (Gel Doc ${ }^{\mathrm{TM}}$ XR, BioRad) were documented by Quantity One analysis software (version 4.6).

\subsection{Statistical Analysis}

Data were calculated with analysis of variance (ANOVA), two-way ANOVA or Student's $t$ test as appropriate using Graph Pad Prism 6.01 and Image J-win64 software. Significance was designated as ${ }^{*}$ for $p<0.05,{ }^{* *}$ for $p<0.01,{ }^{* * *}$ for $p<0.001$, and ${ }^{* * * *}$ for $p<0.0001$. Error bars depict $\pm \operatorname{SD}$ for $n=3$ or $n=4$.

\section{Conclusions}

A phytochemical approach led to the isolation of methylated xanthones from the underground parts of Metaxya rostrata (M, 1, 2 and 3). The structures were elucidated based on thorough 1D and 2D NMR, as well as LC-HRMS measurements. Looking at structure activity relationships, the monomethylated xanthones induced cell loss, activation of caspase and cell cycle arrest in G2/M in CRC cells, indicating that the compounds affected cell proliferation and induced their apoptotic cell death. Interestingly, their cytotoxic effects were reduced compared to those of the unmethylated compounds $\mathrm{XB}$ and $\mathrm{OH}-\mathrm{XB}$. In addition, dimethylation in compound 2 drastically reduced the activity, suggesting that the presence of two methyl groups disrupted the interactions with crucial cellular targets. The target responsible for the cytotoxic activity of these xanthones is unlikely to be the transcription factor FoxM1, because all compounds, including 2, suppressed FoxM1.

The inhibition of topo I correlated with an unmethylated $\mathrm{OH}$-group at position 7 , as shown by the high activity of $\mathrm{OH}-\mathrm{XB}$ versus $\mathrm{XB}$ [12], and by the significant reduction when this $\mathrm{OH}$-group was methylated in compound 2. Compound 1, with its unmethylated $\mathrm{OH}$-group in position 7, displayed considerable inhibition of topo I, i.e., comparable to that of $\mathrm{OH}-\mathrm{XB}$. Unfortunately, we cannot draw any conclusions about 4 , which also carries a methyl group at the $7 \mathrm{OH}$-group, because it was only available in a mixture with 1 . In summary, our observations showed cytotoxic activity of the new xanthones $\mathbf{M}$ and $\mathbf{1}$ for the first time. As topo I inhibitors are highly effective cancer therapeutics [26-28], this defines a promising lead structure for further preclinical investigations using models of CRC, but also other malignancies.

Supplementary Materials: The following are available online, Figure S1: ${ }^{1} \mathrm{H}-\mathrm{NMR}$ spectrum of mixture $\mathbf{M}$ $\left(\mathrm{CD}_{3} \mathrm{OD}, 700.40 \mathrm{MHz}\right)$, Figure S2: ${ }^{13} \mathrm{C}-\mathrm{NMR}$ spectrum of mixture $\mathbf{M}\left(\mathrm{CD}_{3} \mathrm{OD}, 176.12 \mathrm{MHz}\right)$, Figure S3: HSQC spectrum of mixture $\mathbf{M}\left(\mathrm{CD}_{3} \mathrm{OD}\right)$, Figure S4: $\mathrm{HMBC}$ spectrum of mixture $\mathbf{M}\left(\mathrm{CD}_{3} \mathrm{OD}\right)$, Figure S5: NOESY spectrum of mixture $\mathbf{M}\left(\mathrm{CD}_{3} \mathrm{OD}\right)$, Figure S6: MS1 spectrum of mixture $\mathbf{M}$ showing the adduct $[\mathrm{M}+\mathrm{H}]^{+}$, Figure S7: MS1 spectrum of mixture $\mathbf{M}$ showing the adduct $\left[\mathrm{M}-\mathrm{H}^{-}\right.$, Figure S8: MS2 spectrum of mixture $\mathbf{M}$ fragmented using $\mathrm{HCD}$ at $55.0 \mathrm{eV}$, Figure S9: ${ }^{1} \mathrm{H}-\mathrm{NMR}$ spectrum of compound $\mathbf{1}\left(\mathrm{CD}_{3} \mathrm{OD}, 700.40 \mathrm{MHz}\right)$, Figure S10: ${ }^{13} \mathrm{C}-\mathrm{NMR}$ spectrum of compound $\mathbf{1}\left(\mathrm{CD}_{3} \mathrm{OD}, 176.12 \mathrm{MHz}\right)$, Figure S11: $\mathrm{HSQC}$ spectrum of compound $\mathbf{1}\left(\mathrm{CD}_{3} \mathrm{OD}\right)$, Figure S12: HMBC spectrum of compound $\mathbf{1}\left(\mathrm{CD}_{3} \mathrm{OD}\right)$, Figure S13: NOESY spectrum of compound $\mathbf{1}\left(\mathrm{CD}_{3} \mathrm{OD}\right)$, Figure $\mathrm{S} 14$ : MS1 spectrum of compound 1 showing the adduct $[\mathrm{M}+\mathrm{H}]^{+}$, Figure S15: MS1 spectrum of compound 1 showing the adduct $[\mathrm{M}-\mathrm{H}]^{-}$, Figure S16: MS2 spectrum of compound $\mathbf{1}$ fragmented using $\mathrm{HCD}$ at $55.0 \mathrm{eV}$, Figure S17: 
${ }^{1} \mathrm{H}-\mathrm{NMR}$ spectrum of compound $2\left(\mathrm{CD}_{3} \mathrm{OD}, 700.40 \mathrm{MHz}\right)$, Figure S18: ${ }^{13} \mathrm{C}-\mathrm{NMR}$ spectrum of compound 2 $\left(\mathrm{CD}_{3} \mathrm{OD}, 176.12 \mathrm{MHz}\right)$, Figure S19: HSQC spectrum of compound $2\left(\mathrm{CD}_{3} \mathrm{OD}\right)$, Figure S20: HMBC spectrum of compound $2\left(\mathrm{CD}_{3} \mathrm{OD}\right)$, Figure S21: NOESY spectrum of compound $2\left(\mathrm{CD}_{3} \mathrm{OD}\right)$, Figure S22: MS1 spectrum of compound 2 showing the adduct $[\mathrm{M}+\mathrm{H}]^{+}$, Figure S23: MS1 spectrum of compound 2 showing the adduct $[\mathrm{M}-\mathrm{H}]^{-}$, Figure S24: MS2 spectrum of compound 2 fragmented using HCD at $55.0 \mathrm{eV}$, Figure S25: ${ }^{1} \mathrm{H}-\mathrm{NMR}$ spectrum of compound $3\left(\mathrm{CD}_{3} \mathrm{OD}, 700.40 \mathrm{MHz}\right)$, Figure S26: HSQC spectrum of compound $3\left(\mathrm{CD}_{3} \mathrm{OD}\right)$, Figure S27: HMBC spectrum of compound $3\left(\mathrm{CD}_{3} \mathrm{OD}\right)$, Figure S28: NOESY spectrum of compound $3\left(\mathrm{CD}_{3} \mathrm{OD}\right)$, Figure S29: MS1 spectrum of compound 3 showing the adduct $[\mathrm{M}+\mathrm{H}]^{+}$, Figure S30: MS1 spectrum of compound 3 showing the adduct $[\mathrm{M}-\mathrm{H}]^{-}$, Figure S31: MS2 spectrum of compound 3 fragmented using HCD at $55.0 \mathrm{eV}$.

Author Contributions: Conceptualization, E.M., L.K. and B.M.; methodology, E.M., X.H., H.K., A.T., S.R., H.S. and P.H.; formal analysis, E.M., H.K., A.T., H.S., P.H., L.K. and B.M.; writing-original draft preparation, E.M.; writing-review and editing, E.M., B.M., L.K. and H.K.; supervision, L.K. and B.M.; project administration, L.K.; funding acquisition, E.M. All authors have read and agreed to the published version of the manuscript.

Funding: This research was funded by Hochschuljubiläumsstiftung der Stadt Wien (H-211753/2018).

Acknowledgments: Open Access Funding by the University of Vienna.

Conflicts of Interest: The authors declare no conflict of interest. The funders had no role in the design of the study; in the collection, analyses, or interpretation of data; in the writing of the manuscript, or in the decision to publish the results.

\section{References}

1. Cárdenas, G.G.; Tuomisto, H.; Lehtonen, S. Newly discovered diversity in the tropical fern genus Metaxya based on morphology and molecular phylogenetic analyses. Kew Bull. 2016, 71, 5. [CrossRef]

2. Smith, A.; Tuomisto, H.; Pryer, K.; Hunt, J.; Wolf, P. Metaxya lanosa, a Second Species in the Genus and Fern Family Metaxyaceae. Syst. Bot. 2009, 26, 480-486. [CrossRef]

3. Kainz, K.P.; Krenn, L.; Erdem, Z.; Kählig, H.; Zehl, M.; Bursch, W.; Berger, W.; Marian, B. 2-Deprenyl-Rheediaxanthone B Isolated from Metaxya rostrata Induces Active Cell Death in Colorectal Tumor Cells. PLoS ONE 2013, 8, e65745. [CrossRef]

4. Waltenberger, B.; Atanasov, A.G.; Heiss, E.H.; Bernhard, D.; Rollinger, J.M.; Breuss, J.M.; Schuster, D.; Bauer, R.; Kopp, B.; Franz, C.; et al. Drugs from nature targeting inflammation (DNTI): A successful Austrian interdisciplinary network project. Mon. für Chem.-Chem. Mon. 2016, 147, 479-491. [CrossRef] [PubMed]

5. Khazir, J.; Riley, D.L.; Pilcher, L.A.; De Maayer, P.; Mir, B.A. Anticancer Agents from Diverse Natural Sources. Nat. Prod. Commun. 2014, 9, 1655-1669. [CrossRef] [PubMed]

6. Newman, D.J.; Cragg, G.M. Natural Products as Sources of New Drugs from 1981 to 2014. J. Nat. Prod. 2016, 79, 629-661. [CrossRef]

7. Ye, J.; Zhang, R.; Wu, F.; Zhai, L.; Wang, K.; Xiao, M.; Xie, T.; Sui, X. Non-apoptotic cell death in malignant tumor cells and natural compounds. Cancer Lett. 2018, 420, 210-227. [CrossRef]

8. Krajarng, A.; Nakamura, Y.; Suksamrarn, S.; Watanapokasin, R. $\alpha$-Mangostin Induces Apoptosis in Human Chondrosarcoma Cells through Downregulation of ERK/JNK and Akt Signaling Pathway. J. Agric. Food Chem. 2011, 59, 5746-5754. [CrossRef]

9. Krajarng, A.; Nilwarankoon, S.; Suksamrarn, S.; Watanapokasin, R. Antiproliferative effect of $\alpha$-mangostin on canine osteosarcoma cells. Res. Veter. Sci. 2012, 93, 788-794. [CrossRef]

10. Watanapokasin, R.; Jarinthanan, F.; Nakamura, Y.; Sawasjirakij, N.; Jaratrungtawee, A.; Suksamrarn, S. Effects of $\alpha$-mangostin on apoptosis induction of human colon cancer. World J. Gastroenterol. 2011, 17, 2086-2095. [CrossRef]

11. Mittermair, E.; Krenn, L.; Marian, B. Prenylated xanthones from Metaxya rostrata suppress FoxM1 and induce active cell death by distinct mechanisms. Phytomedicine 2019, 60, 152912. [CrossRef] [PubMed]

12. Mittermair, E.; Schueffl, H.; Heffeter, P.; Krenn, L.; Marian, B. Destabilization of FoxM1 and Inhibition of Topoisomerase I Contribute to Cytotoxicity of Prenylated Xanthones Isolated from Metaxya rostrata. Planta Med. 2020. [CrossRef] [PubMed]

13. Klein-Júnior, L.C.; Campos, A.; Niero, R.; Corrêa, R.; Heyden, Y.V.; Filho, V.C. Xanthones and Cancer: From Natural Sources to Mechanisms of Action. Chem. Biodivers. 2020, 17, e1900499. [CrossRef] [PubMed]

14. Akao, Y.; Nakagawa, Y.; Nozawa, Y.; Iinuma, M. Anti-Cancer Effects of Xanthones from Pericarps of Mangosteen. Int. J. Mol. Sci. 2008, 9, 355-370. [CrossRef] [PubMed] 
15. Matsumoto, K.; Akao, Y.; Yi, H.; Ohguchi, K.; Ito, T.; Tanaka, T.; Kobayashi, E.; Iinuma, M.; Nozawa, Y. Preferential target is mitochondria in $\alpha$-mangostin-induced apoptosis in human leukemia HL60 cells. Bioorg. Med. Chem. 2004, 12, 5799-5806. [CrossRef]

16. Gong, D.; Ferrell, J.E. The Roles of Cyclin A2, B1, and B2 in Early and Late Mitotic Events. Mol. Boil. Cell 2010, 21, 3149-3161. [CrossRef]

17. Khongkow, P.; Gomes, A.R.; Gong, C.; Man, E.P.S.; Tsang, J.W.-H.; Zhao, F.; Monteiro, L.J.; Coombes, R.C.; Medema, R.; Khoo, U.-S.; et al. Paclitaxel targets FOXM1 to regulate KIF20A in mitotic catastrophe and breast cancer paclitaxel resistance. Oncogene 2015, 35, 990-1002. [CrossRef]

18. Wierstra, I. FOXM1 (Forkhead box M1) in Tumorigenesis: Overexpression in human cancer, implication in tumorigenesis, oncogenic functions, tumor-suppressive properties, and target of anticancer therapy. In Advances in Cancer Research; Academic Press: Cambridge, UK, 2013; pp. 191-419. [CrossRef]

19. Wierstra, I. The Transcription Factor FOXM1 (Forkhead box M1): Proliferation-specific expression, transcription factor function, target genes, mouse models, and normal biological roles. In Advances in Cancer Research; Academic Press: New York, NY, USA, 2013; pp. 97-398. [CrossRef]

20. Yao, S.; Fan, L.Y.-N.; Lam, E.W.-F. The FOXO3-FOXM1 axis: A key cancer drug target and a modulator of cancer drug resistance. Semin. Cancer Boil. 2018, 50, 77-89. [CrossRef]

21. Li, H.; Huang, J.; Yang, B.; Xiang, T.; Yin, X.; Peng, W.; Cheng, W.; Wan, J.; Luo, F.; Li, H.; et al. Mangiferin exerts antitumor activity in breast cancer cells by regulating matrix metalloproteinases, epithelial to mesenchymal transition, and $\beta$-catenin signaling pathway. Toxicol. Appl. Pharmacol. 2013, 272, 180-190. [CrossRef]

22. Halasi, M.; Gartel, A.L. Targeting FOXM1 in cancer. Biochem. Pharmacol. 2013, 85, 644-652. [CrossRef]

23. Kainz, K. Phytochemical Investigation and Bioactivity-Guided Isolation of Cytotoxic Compounds from Metaxya rostrata. Ph.D. Thesis, University of Vienna, Vienna, Austria, 2011.

24. Erdem, Z.N.; Schwarz, S.; Drev, D.; Heinzle, C.; Reti, A.; Heffeter, P.; Hudec, X.; Holzmann, K.; Grasl-Kraupp, B.; Berger, W.; et al. Irinotecan Upregulates Fibroblast Growth Factor Receptor 3 Expression in Colorectal Cancer Cells, Which Mitigates Irinotecan-Induced Apoptosis. Transl. Oncol. 2017, 10, 332-339. [CrossRef] [PubMed]

25. Dornetshuber, R.; Heffeter, P.; Lemmens-Gruber, R.; Elbling, L.; Marko, D.; Micksche, M.; Berger, W. Oxidative stress and DNA interactions are not involved in Enniatin- and Beauvericin-mediated apoptosis induction. Mol. Nutr. Food Res. 2009, 53, 1112-1122. [CrossRef] [PubMed]

26. Evdokimov, N.M.; Van Slambrouck, S.; Heffeter, P.; Tu, L.; Le Calvé, B.; Lamoral-Theys, D.; Hooten, C.J.; Uglinskii, P.Y.; Rogelj, S.; Kiss, R.; et al. Structural Simplification of Bioactive Natural Products with Multicomponent Synthesis. 3. Fused Uracil-Containing Heterocycles as Novel Topoisomerase-Targeting Agents. J. Med. Chem. 2011, 54, 2012-2021. [CrossRef] [PubMed]

27. Gonzalez-Ruiz, V.; Pascua, I.; Fernández-Marcelo, T.; Ribelles, P.; Bianchini, G.; Sridharan, V.; Iniesta, P.; Ramos, M.T.; Olives, A.I.; Martín, M.A.; et al. B-Ring-Aryl Substituted Luotonin A Analogues with a New Binding Mode to the Topoisomerase 1-DNA Complex Show Enhanced Cytotoxic Activity. PLoS ONE 2014, 9 , e95998. [CrossRef]

28. Nitiss, J.L.; Soans, E.; Rogojina, A.; Seth, A.; Mishina, M. Topoisomerase Assays. Curr. Protoc. Pharmacol. 2012, 57, 3.3.1-3.3.27. [CrossRef]

Sample Availability: Samples of the compounds only available after repetition of isolation from the authors.

(C) 2020 by the authors. Licensee MDPI, Basel, Switzerland. This article is an open access article distributed under the terms and conditions of the Creative Commons Attribution (CC BY) license (http://creativecommons.org/licenses/by/4.0/). 